\title{
The relationship between firm productivity, firm size and CSR objectives for innovations
}

\author{
Pål Børing ${ }^{1}$
}

Received: 24 September 2018 / Revised: 27 January 2019 / Accepted: 8 March 2019 /

Published online: 16 March 2019

(C) The Author(s) 2019

\begin{abstract}
We examine how a firm's productivity level is related to its potential corporate social responsibility (CSR) objectives for innovations, and whether this relationship is affected by firm size. Two CSR objectives for innovations are examined: a firm's objective of reducing environmental impacts, and an objective of improving health or safety of the employees. Firm size is measured by the number of employees. A data set comprising Norwegian manufacturing firms with or without innovation activity is used. The estimation results show that the predicted probability of adopting the objective of reducing environmental impacts has a significant negative effect on the productivity level among large firms while this effect is not significant among small firms. The predicted probability of adopting the objective of improving health or safety of the employees has no significant effect on the productivity level of small or large firms. These results indicate that whether 'it pays to be green' or not, depends on firm size. The article offers a resource argument in order to explain the different results between small and large firms.
\end{abstract}

Keywords Manufacturing firms · Productivity level $\cdot$ Firm size $\cdot$ CSR objectives for innovations $\cdot$ Innovation activity $\cdot$ Product and process innovation

JEL Classification $\mathrm{C} 13 \cdot \mathrm{D} 24 \cdot \mathrm{L} 60 \cdot \mathrm{O} 31$

\section{Introduction}

Corporate social responsibility (CSR) has become an important issue for firms. As pointed out by Torelli et al. (2012), CSR activities can contribute positively to longterm shareholder value. The benefits of CSR are also related to its effect on corporate reputation (Walker and Dyck 2014). Poor social and environmental ratings

\section{Pål Børing}

paal.boring@nifu.no

1 NIFU (Nordic Institute for Studies in Innovation, Research and Education), P.O. Box 2815,

Tøyen, 0608 Oslo, Norway 
can have a negative impact on a firm's performance and reputation (Chatterji et al. 2009). This emphasizes the importance of examining how CSR is related to a firm's performance.

The relationship between CSR and firm performance has been studied extensively (see, for example, Bai and Chang 2015, and Saeidi et al. 2015). According to Bocquet et al. (2017), few studies have analyzed the impact of a combined strategy of innovation and CSR on firm performance; these studies focus mainly on financial performance. Bocquet et al. (2017) instead consider the simultaneous impact of technological innovations and CSR on firm growth.

The present study is based on an alternative approach to that employed in Bocquet et al. (2017). One purpose of this study is to examine how a firm's performance is related to its potential CSR objectives for innovations. Another purpose is to examine whether this relationship is affected by firm size, since firm size can influence the link between CSR and firm performance (Youn et al. 2015). A firm's performance is measured by its productivity level. Although several previous studies have focused on the effect of innovation on the productivity level (see Sect. 2), we know far less about how a firm's productivity level is influenced by its potential CSR objectives for innovations, and whether firm size can affect this influence. The aim of this article is to generate new knowledge concerning the relationship between a firm's productivity, its size and potential CSR objectives for innovations.

Several theoretical frameworks have been used to examine CSR. One is the agency theory perspective (Wright and Ferris 1997). Another is the corporate social performance (CSP) framework (Wood 1991). A third framework is the stakeholder perspective (Freeman 1984). McWilliams and Siegel (2001) claim that the CSP model has much in common with the stakeholder perspective, which is the most widely used theoretical framework' (p. 118). They instead outline an alternative theoretical perspective, and emphasize that 'this framework allows us to develop a set of hypotheses regarding the determinants and consequences of CSR' (pp. 118-119).

We consider the CSR model in McWilliams and Siegel (2001) as an analytical framework for this study. Their analysis reveals that there is some level of CSR that will maximize a firm's profit, while also satisfying stakeholder demand for CSR. By maximizing profit, 'the firm meets the demands of relevant stakeholders-both those that demand CSR (consumers, employees, community) and those that 'own' the firm (shareholders)' (p. 125).

There are different definitions of CSR. Based on McWilliams and Siegel (2001, p. 117), Here we define CSR as actions that appear to further some social good, beyond the interests of the firm and that which is required by law. They emphasize that 'this definition underscores that, to us, CSR means going beyond obeying the law'.

Based on this CSR definition, we examine two CSR objectives for innovations: a firm's objective of reducing environmental impacts, and an objective of improving health or safety of the employees. ${ }^{1}$ Both CSR objectives are schemes for health,

\footnotetext{
${ }^{1}$ Based on the analyses in Katkalo et al. (2010), we do not classify a given objective as purely internal or external, since the objectives may be interrelated.
} 
safety and the environment. Product and process innovations that are developed with the objective of reducing environmental impacts can also be defined as eco-innovations (Díaz-García et al. 2015). As far as we are aware, no previous study has examined how a firm's productivity level is related to the two CSR objectives for innovations, and whether this relationship is influenced by firm size.

The rest of the article is organized as follows. Section 2 presents previous relevant studies, and the hypotheses in the analysis. In Sect. 3, we describe the data set. Section 4 presents the econometric approach. Descriptive statistics are provided in Sect. 5. In Sect. 6, we present the estimation results. Conclusions are given in Sect. 7.

\section{Previous relevant studies and the hypotheses}

Several studies have examined how innovation is related to firms' performance (including productivity) or survival. Banbury and Mitchell (1995) show that introducing incremental product innovations during its tenure as an industry incumbent strongly influences a business's market share and indirectly, its survival. Cefis and Marsili (2006) find that innovation has a positive effect on the probability of firms' survival, while Audretsch (1995) concludes that variations in new firms' opportunity to innovate shapes variations in their survival and growth rates across industrial sectors. Distinguishing between product and process innovation, Cefis and Marsili (2005) show that firms which can implement process innovation benefit particularly as shown in a higher survival likelihood.

Both Cainelli et al. $(2004,2006)$ find that innovation has a positive impact on productivity in services. Black and Lynch (2004) conclude that "workplace innovation, especially when it has occurred in unionized establishments, is positively associated with labor productivity in the US' (p. F113). Crépon et al. (1998) find that firm productivity correlates positively with a higher innovation output, even when controlling for the skill composition of labor as well as for physical capital intensity. The findings in Hashi and Stojčić (2013) reveal a positive relationship between innovation activities and firm productivity. Based on data of Italian manufacturing firms, Hall et al. (2013) find that R\&D and information and communication technology (ICT) are both strongly associated with innovation and productivity, with R\&D being more important for innovation, and ICT investment being more important for productivity.

Surveying empirical evidence on the relationship between innovation and productivity in firms, Hall (2011) concludes that there is a positive impact of product innovation on productivity, but that the impact of process innovation is more ambiguous. Baumann and Kritikos (2016) find a sizable effect of product innovation on productivity, but no significant effect of process innovation. In contrast, both product and process innovation have a positive impact on firm's productivity in Hall et al. (2009), especially process innovation. All four types of innovation considered in 
Mohnen and Hall (2013) (product, process, organizational and marketing innovations) contribute to a better productivity performance. ${ }^{2}$

In the light of the focus in this article, we highlight the studies by Hart and Ahuja (1996), Russo and Fouts (1997), King and Lenox (2002), Ghisetti and Rennings (2014), Bocquet et al. (2017), Stoian and Gilman (2017), and Buhai et al. (2017). Ghisetti and Rennings (2014) focus on environmental innovations and firm profitability. Their results show that whether it pays to be green or not, depends on how to be green; it pays to be green for innovations leading to a reduction in the use of energy and resources while it does not pay to be green for innovations aimed at reducing externalities. Buhai et al. (2017) examine the impact of workplace health and safety practices on firm performance. They find positive and large productivity effects of improved physical dimensions of the health and safety environment. The findings in Bocquet et al. (2017) confirm that innovation plays a significant role in determining the relationship between CSR and firm growth.

The results in Hart and Ahuja (1996) suggest that it pays to be green, and the results in Russo and Fouts (1997) also indicate this. Hart and Ahuja (1996) conclude that efforts to reduce emissions through pollution prevention appear to drop to the bottom line within one to 3 years after initiation, and that those firms with the highest emission levels stand to gain the most. Russo and Fouts (1997) find support for their hypothesis that high levels of environmental performance will be associated with enhanced profitability. Stoian and Gilman (2017) point out that CSR activities related to the environment can attract better employees and managers which can lead to increased productivity and efficiency. The analysis in King and Lenox (2002) supports the 'pays to be green' hypothesis. They find strong evidence that waste prevention leads to financial gain, but they find no evidence whereby firms profit from reducing pollution by other means.

Based on the studies above, we are unable to draw any unambiguous conclusions about the effect of the objective of reducing environmental impacts on a firm's productivity level. In line with the analyses in Hart and Ahuja (1996), Russo and Fouts (1997), and King and Lenox (2002), the productivity level is, however, expected to be positively and significantly affected by the predicted probability of adopting this objective. The predicted probability of adopting the objective of improving health or safety of the employees is also expected to have a positive and significant effect on productivity, based on the study by Buhai et al. (2017). We therefore formulate the following two hypotheses:

H1: The productivity level is positively affected by the predicted probability of adopting the objective of reducing environmental impacts.

H2: The productivity level is positively affected by the predicted probability of adopting the objective of improving health or safety of the employees.

The two hypotheses are tested using regression techniques.

\footnotetext{
2 Mohnen and Hall (2013) mention that other ways to categorise innovations are as 'innovations with an environmental objective (environmental innovations)' (p. 49).
} 


\section{The data set}

The data set used comprised Norwegian firms and is based on three data sources. The first data source is matched employer-employee register data from Statistics Norway that contains information on all employees aged 15 years and above, and all plants and enterprises, in Norway in 2013. In the employer-employee register data, both plants and enterprises are identified by unique codes. There is a corresponding unique enterprise code to each plant's unique code, where an enterprise consists of at least one plant.

The second data source is innovation data from the Norwegian Innovation Survey for 2013 which is an independent survey conducted by Statistics Norway in one of the 'middle years' of the Community Innovation Survey (CIS). This survey contains information on innovation activity in the Norwegian business enterprise sector for 2013, and measures the extent to which firms have introduced product or process innovations during the period 2011-2013. The survey covers firms with at least 5 employees in most industrial sectors, while in certain industries (NACE codes F41-43, H49-53 and I56) only firms with at least 20 employees are included.

Firms are identified at the enterprise level in the innovation data, where enterprises are identified by unique codes. The enterprise codes in the innovation data correspond to the enterprise codes in the employer-employee register data. It is therefore possible to link the employer-employee data to the innovation data at the enterprise level based on the enterprise codes.

The third data source is data from the Amadeus database at the Nordic Institute for Studies in Innovation, Research and Education (NIFU) provided by Bureau van Dijk. From this database, we use information about the average annual capital stock for firms in Norway for the period 2012-2014. For each year, the capital stock is equal to total assets which is the sum of current and long-term assets. Total assets are measured in 1000 NOK. The unit in the Amadeus data is industrial sector (four-digit NACE code level, SIC2007). Thus, it is not possible to link the Amadeus data to the employer-employee register data or the innovation data at the enterprise level, only at the industrial level.

Firms are defined at the enterprise level in the analysis since this unit is employed in the innovation survey, and also because turnover is defined at the enterprise level in the matched employer-employee register data. The process of matching the three data sources together is as follows: First, we link the matched employer-employee register data to the innovation data at the enterprise level based on the enterprise codes. These combined data are then linked to the Amadeus data at the industrial level (merged using the four-digit NACE codes, SIC2007). As a result, we have no information about the capital stock of each firm, only the capital stock in the industrial sectors where each firm is included. 


\subsection{The sample of firms}

Crespi et al. (2006) conclude that service sector data are particularly problematic for use in productivity calculations. Therefore, the sample only consists of firms in the Norwegian manufacturing sector. It follows that the sample covers firms with at least 5 employees in all included industries since the manufacturing sector is classified by the NACE codes C10-33.

There are 1822 manufacturing firms in the data set. Of these, 1020 are firms with innovation activity, and 802 are firms without innovation activity. Three of the firms with innovation activity are excluded from the analyses since they have missing values for at least one of the explanatory variables. ${ }^{3}$ This reduces the sample to 1819 firms. We also exclude 13 firms with missing values for the dependent variable (three firms with innovation activity and 10 firms without innovation activity). The final sample therefore consists of 1014 firms with innovation activity and 792 firms without innovation activity, i.e. 1806 manufacturing firms in total.

Firms with innovation activity include not only product- and/or process-innovative firms, but also firms engaged in innovation activities that did not result in a product or process innovation during the period 2011-2013 because the activities were abandoned or suspended before completion, or were still ongoing at the end of the 2013. ${ }^{4}$ Product-innovative firms have introduced a product (good or service) that is new or significantly improved with respect to its capabilities, user friendliness, components or sub-systems during the period 2011-2013. Process-innovative firms have implemented a new or significantly improved production process, distribution method, or supporting activity during the same period.

\subsection{The data representativeness}

Linking the innovation data to the matched employer-employee register data can have an impact on the representativeness of the data set used in the analysis since there are no enterprises with fewer than 5 employees included in the innovation survey. Weighted descriptive statistics of the innovation data show that on average the proportion of the 1020 firms with innovation activity among the 1822 manufacturing firms in the data set increases with the number of employees. We find that this proportion is $42 \%$ for manufacturing enterprises with 5-9 employees, $45 \%$ for manufacturing enterprises with 10-49 employees, 55\% for manufacturing enterprises with 50-99 employees, 71\% for manufacturing enterprises with at least 100 employees, and $46 \%$ for all manufacturing enterprises in the innovation survey (weighted results). Based on these results, we conclude that our linking procedure not only

\footnotetext{
3 The exception is firms with missing values for some of their employees' educational level. Employees with unknown educational level are included in a separate category in the empirical analysis.

4 Based on the innovation data, we are not able to distinguish between firms engaged in innovation activities that did not result in a product innovation and those engaged in such activities that did not result in a process innovation during the period 2011-2013.
} 
introduces a bias in favor of larger-sized firms, but also a bias in favor of firms with innovation activity.

In order to account for these biases, all the empirical results in Sects. 5 and 6 are weighted using sampling weights from the innovation data. The average value of the weights, $\bar{w}$, is higher among the 792 manufacturing enterprises without innovation activity $(\bar{w}=3.2)$ than among the 1014 manufacturing enterprises with innovation activity $(\bar{w}=2.1)$ in the final sample. Furthermore, $\bar{w}=5.3$ among the 313 manufacturing enterprises with 5-9 employees, $\bar{w}=2.9$ among the 784 manufacturing enterprises with 10-49 employees, $\bar{w}=1.0$ among the 709 manufacturing enterprises with at least 50 employees, and $\bar{w}=2.6$ among the 1806 manufacturing enterprises in the final sample.

\subsection{The variables}

The variables used in the analysis are the dependent variable and the explanatory variables. The set of explanatory variables consists of the key regressors and the control variables. In this section, we give a presentation of the variables. In Table 4 in the Appendix, we specify the source of the dependent variable and each of the explanatory variables.

The dependent variable is equal to the log of the productivity level. This level is defined as the firm's production value per employee. Thus, the productivity level is measured by the (average) labor productivity. The production value is measured by the turnover given in $1000 \mathrm{NOK}$.

The key regressors are the explanatory variables that account for the CSR objectives for innovations. In the CIS survey, firms were asked about the importance each of the following objectives for their activities in developing product or process innovations during the period 2011-2013 5 : (1) increase range of goods or services, (2) replace outdated products or processes, (3) enter new markets or increase market share, (4) improve quality of goods or services, (5) improve flexibility for producing goods or services, (6) increase capacity for producing goods or services, (7) reduce labour costs per unit output, (8) reduce material and energy costs per unit output, (9) reduce environmental impacts, and (10) improve health or safety of their employees. ${ }^{6}$ Each of the 1014 firms with innovation activity in the final sample has answered the question about the objectives for innovations (1) to (10), and many of these firms have answered that several of these objectives are highly or moderately important. None of the 792 firms without innovation activity have answered the question about the objectives for innovations.

\footnotetext{
5 Since the term 'objective' is used in the CIS questionnaire, we use this term in the article, and not the term 'strategy' which is used, for example, in Bocquet et al. (2017).

6 The objectives (1) to (10) are related to firms' activities in developing product or process innovations. It follows that the sample does not include firms that introduced organizational or marketing innovations during the period 2011-2013, as long as these firms are not included in the group of 'firms with innovation activity'.
} 
There are at least three potential CSR objectives for innovations. They are denoted 'material and energy costs objective', 'environmental objective', and 'health or safety objective'. All are dummy variables. The variable denoted 'material and energy costs objective' is equal to 1 if a firm stated that (8)-reduce material and energy costs per unit output-is (highly or moderately) important, and 0 otherwise. The variable denoted 'environmental objective' is equal to 1 if a firm stated that (9) - reduce environmental impacts-is important, and 0 otherwise. The variable denoted 'health or safety objective' is equal to 1 if a firm stated that (10)-improve health or safety of their employees - is important, and 0 otherwise. Firms that adopt the 'material and energy costs objective' have the objective of reducing material and energy costs per unit output, those which adopt the 'health or safety objective' have the objective of improving health or safety of their employees, and those which adopt the 'environmental objective' have the objective of reducing environmental impacts.

Firms that adopt the 'material and energy costs objective' may have a CSR objective for innovations, since this objective can be considered as a health, safety and environment scheme, and as a type of environmental innovation (Ghisetti and Rennings 2014). Energy/material cost reductions can also influence eco-innovation types (del Río et al. 2017). On the other hand, those which adopt the 'material and energy costs objective' may use this objective only with the goal of maximising profit. Given the adopted definition of CSR in Sect. 1, we consider the "environmental objective' and the 'health or safety objective', but not the 'material and energy costs objective', as CSR objectives for innovations. We therefore do not focus on the 'material and energy costs objective' in the analysis.

As a consequence, there are two key regressors: the 'environmental objective', and the 'health or safety objective'. Both key regressors are equal to 0 if a firm neither adopts the 'environmental objective' nor the 'health or safety objective'.

Explanatory variables other than the key regressors are the following control variables (studies in parenthesis relate each control variable to firm productivity) ${ }^{7}$ :

- The log of the average capital intensity (measured as the average capital stock per employee where the capital stock is equal to total assets) in those industries where firms are included (Syverson 2011),

- the log of the number of employees (Syverson 2011),

- firm age (Haltiwanger et al. 1999; Jensen et al. 2001),

- proportion of females of total employees (Hellerstein and Neumark 1999; Pfeifer and Wagner 2014),

- average age of employees (Syverson 2011; van Ours and Stoeldraijer 2011; Pfeifer and Wagner 2014),

- educational level (measured as proportions of employees at different highest attained educational levels) (Syverson 2011),

\footnotetext{
7 Syverson (2011) surveys the recent literature on determinants of productivity, where productivity is linked to several factors (e.g. a number of features of technology, demand and market structure, trade, and firms' organizational structures).
} 
- geographic markets (measured as the markets where the firms sell their products, either only in the Norwegian market, only abroad, or both in Norway and abroad) (Syverson 2011),

- innovation activity (Hall et al. 2009; Hall 2011; Mohnen and Hall 2013; Baumann and Kritikos 2016), and

- manufacturing industrial sectors (two-digit NACE code level, SIC2007) (Syverson 2011).

A firm's age is equivalent to the number of years from the founding year (or the year of establishment) until 2013, varying between 1 and 115 years in the final sample. A firm's founding year is determined as follows: In the employer-employee data, enterprises are identified by unique codes. These data also contain information concerning when these unique codes were created, and we define the year an enterprise code was created as the firm's founding year.

We differentiate between the following highest attained educational levels: employees with primary, secondary or higher education. The dummy variable 'innovation activity' is equal to 1 if a firm has innovation activity, and 0 otherwise.

\section{The econometric approach}

\subsection{The potential endogeneity problem}

There is a potential endogeneity problem associated with the variables that account for CSR objectives for innovations. One possibility is that we have a causality direction in the way that a firm's productivity level is affected by its adoption of CSR objectives for innovations. This is the basis for the analyses conducted in this article, and based on previous studies (cf. Sect. 2). We may also have the opposite causality direction from productivity to the adoption of CSR objectives for innovations: a firm with aiming to increase its production value for a given stock of employees (i.e. increase its productivity level) may, for example, choose to adopt such objectives for innovations in order to improve its reputation, which in turn may have a positive impact on its performance. Thus, the causality may not only be that adopting CSR objectives for innovations can have an impact on productivity, but also that productivity can affect the adoption of such objectives.

Similarly, we may have a causality direction from productivity to the adoption of other objectives for innovations than CSR objectives. Since only firms with innovation activity have answered the question about the objectives for innovations, there is also a potential endogeneity problem associated with the variable 'innovation activity'.

Endogeneity results in inconsistent estimators of the parameters in linear models (Wooldridge 2002). In the analysis we use a two-step procedure described in Sect. 4.4 based on the three-step model in Hall et al. (2009, 2013). The applied procedure is a way to account for possible endogeneity issues concerning the variables that account for CSR objectives for innovations. The procedure also accounts for 
potential sample selection bias due to the variable 'innovation activity' and potential bias due to limited available information, as described in Sect. 4.2.

\subsection{Potential sample selection bias and bias due to limited available information}

There are at least two types of potential bias related to the final sample of firms: (i) potential sample selection bias, and (ii) potential bias due to limited available information on certain variables. The potential bias in (ii) applies to the fact that only firms with innovation activity have answered the question about the objectives for innovations. Thus, the two dummy variables that account for the CSR objectives for innovations are only available for firms with innovation activity. All other variables used in the analysis are available for both firms with and without innovation activity. The potential bias in (ii) is accounted for in the two-step procedure described in Sect. 4.4 by using two continuous variables in the regressions instead of the two dummy variables that account for the CSR objectives for innovations. The two continuous variables are the predicted values of the two dummy variables. Since each of the two continuous variables takes values for both firms with and without innovation activity, the estimation results are based on all firms in the final sample (i.e. both those with and without innovation activity). In order to account for the potential bias in (i), we use a binary treatment model in the second step of the two-step procedure.

With reference to type (i) above, there is a potential sample selection bias due to firm survival rates since we include the dummy variable 'innovation activity' in the set of explanatory variables. The reason is that the survival probability of innovative firms is higher than that of non-innovative firms (Cefis and Marsili 2006). Innovative firms may thus be older than non-innovative firms, on average. It follows that innovative firms may be larger than non-innovative firms since in most cases larger firms are older firms (Heyman 2007). This was also shown in Sect. 3.2 for the 1822 manufacturing firms in the data set.

Table 1 shows that the average number of employees in each firm is much higher among firms with innovation activity than among those without innovation activity in the final sample. The educational level is also higher among the employees in the firms with innovation activity than among the employees in the firms without innovation activity, on average. This follows from the fact that the proportion of employees with primary education is lower, and the proportion of employees with higher education is higher, among firms with innovation activity than among those without. The proportion of firms that sell their products both in Norway and abroad is relatively higher, and the proportion of firms selling their products only in the Norwegian market is relatively lower, among firms with innovation activity. However, the proportion of females of total employees and the average age of employees are the same among firms with and without innovation activity.

\subsection{The model specification}

The empirical model is based on the productivity models used in Børing (2014). Let $Y_{i}$ be the monetary value of the production, $L_{i}$ the number of employees, $K_{i}$ 
Table 1 Descriptive statistics, final sample of firms by innovation activity status, weighted results

\begin{tabular}{|c|c|c|c|}
\hline & $\begin{array}{l}\text { With innovation } \\
\text { activity }\end{array}$ & $\begin{array}{l}\text { Without innovation } \\
\text { activity }\end{array}$ & $\begin{array}{l}\text { Final } \\
\text { sample }\end{array}$ \\
\hline Average number of employees & 62 & 25 & 43 \\
\hline Proportion of females of total employees & $24 \%$ & $24 \%$ & $24 \%$ \\
\hline Average age of employees & 43 & 43 & 43 \\
\hline \multicolumn{4}{|l|}{ Educational level (\%) } \\
\hline Employees with primary education & $36 \%$ & $42 \%$ & $39 \%$ \\
\hline Employees with secondary education & $40 \%$ & $41 \%$ & $40 \%$ \\
\hline Employees with higher education & $18 \%$ & $11 \%$ & $14 \%$ \\
\hline Employees with unknown educational level & $6 \%$ & $6 \%$ & $6 \%$ \\
\hline \multicolumn{4}{|l|}{ Geographic markets } \\
\hline Only sell products in the Norwegian market & $53 \%$ & $78 \%$ & $66 \%$ \\
\hline Only sell products abroad & $3 \%$ & $2 \%$ & $2 \%$ \\
\hline Sell products both in Norway and abroad & $44 \%$ & $20 \%$ & $32 \%$ \\
\hline \multicolumn{4}{|l|}{ CSR objectives for innovations } \\
\hline Environmental objective & $64 \%$ & & \\
\hline Health or safety objective & $71 \%$ & & \\
\hline \multicolumn{4}{|l|}{ Industrial sector } \\
\hline Manufacture of food products (10) & $21 \%$ & $17 \%$ & $19 \%$ \\
\hline Manufacture of beverages (11) & $1 \%$ & $0.4 \%$ & $1 \%$ \\
\hline Manufacture of textiles (13) & $2 \%$ & $2 \%$ & $2 \%$ \\
\hline Manufacture of wearing apparel (14) & $1 \%$ & $1 \%$ & $1 \%$ \\
\hline $\begin{array}{l}\text { Manufacture of wood and products of wood } \\
\text { and cork (16) }\end{array}$ & $8 \%$ & $10 \%$ & $9 \%$ \\
\hline Manufacture of paper and paper products (17) & $1 \%$ & $1 \%$ & $1 \%$ \\
\hline Printing and reproduction of recorded media (18) & $5 \%$ & $5 \%$ & $5 \%$ \\
\hline $\begin{array}{l}\text { Manufacture of chemicals and chemical } \\
\text { products (20) }\end{array}$ & $3 \%$ & $1 \%$ & $2 \%$ \\
\hline $\begin{array}{l}\text { Manufacture of basic pharmaceutical products and } \\
\text { pharmaceutical preparations }(21)\end{array}$ & $1 \%$ & $0.2 \%$ & $0.3 \%$ \\
\hline Manufacture of rubber and plastic products (22) & $4 \%$ & $2 \%$ & $3 \%$ \\
\hline Manufacture of non-metallic mineral products (23) & $4 \%$ & $6 \%$ & $5 \%$ \\
\hline Manufacture of basic metals (24) & $2 \%$ & $1 \%$ & $1 \%$ \\
\hline $\begin{array}{l}\text { Manufacture of fabricated metal products, except } \\
\text { machinery and equipment (25) }\end{array}$ & $13 \%$ & $21 \%$ & $17 \%$ \\
\hline $\begin{array}{l}\text { Manufacture of computer, electronic and optical } \\
\text { products (26) }\end{array}$ & $4 \%$ & $1 \%$ & $2 \%$ \\
\hline Manufacture of electrical equipment (27) & $3 \%$ & $2 \%$ & $3 \%$ \\
\hline Manufacture of machinery and equipment n.e.c. (28) & $11 \%$ & $5 \%$ & $8 \%$ \\
\hline $\begin{array}{l}\text { Manufacture of motor vehicles, trailers and semi- } \\
\text { trailers (29) }\end{array}$ & $2 \%$ & $1 \%$ & $2 \%$ \\
\hline Manufacture of other transport equipment (30) & $3 \%$ & $5 \%$ & $4 \%$ \\
\hline Manufacture of furniture (31) & $5 \%$ & $3 \%$ & $4 \%$ \\
\hline Other manufacturing $(15,19,32)$ & $2 \%$ & $5 \%$ & $3 \%$ \\
\hline
\end{tabular}


Table 1 (continued)

\begin{tabular}{llll}
\hline & $\begin{array}{l}\text { With innovation } \\
\text { activity }\end{array}$ & $\begin{array}{l}\text { Without innovation } \\
\text { activity }\end{array}$ & $\begin{array}{l}\text { Final } \\
\text { sample }\end{array}$ \\
\hline $\begin{array}{l}\text { Repair and installation of machinery and equipment } \\
\text { (33) }\end{array}$ & $5 \%$ & $11 \%$ & $8 \%$ \\
Number of enterprises & 1014 & 792 & 1806 \\
Population size & 2168 & 2497 & 4665 \\
\hline
\end{tabular}

Two-digit NACE codes in parenthesis for industrial sector

the monetary value of the capital stock, and $T_{i}$ the state of technology, in firm $i$, $i=1,2, \ldots, n$. The production function is then:

$$
Y_{i}=F_{i}\left(K_{i}, L_{i}, T_{i}\right)=A_{i} K_{i}^{p} L_{i}^{q} T_{i},
$$

where $A_{i}$ represents the Hicksian neutral efficiency level, which is not observable. The function in (1) is of Cobb-Douglas form with parameters $(p, q)$, and has nonconstant returns to scale in $\left(K_{i}, L_{i}\right)$ if $d=p+q \neq 1$. It follows that the production function can be rewritten in terms of labour productivity as

$$
\frac{Y_{i}}{L_{i}}=A_{i}\left(\frac{K_{i}}{L_{i}}\right)^{p} L_{i}^{d-1} T_{i}
$$

Let $\mathbf{X}_{i}$ denotes a row vector of the key regressors, $\mathbf{Z}_{i}$ denotes a row vector of control variables other than $\left(\ln \left(K_{i} / L_{i}\right), \ln L_{i}\right)$, and $\mathbf{b}$ and $\mathbf{c}$ denote column vectors of coefficients. We then model technology $T_{i}$ in the following way:

$$
T_{i}=\exp \left(\mathbf{X}_{i} \mathbf{b}+\mathbf{Z}_{i} \mathbf{c}\right) \text {. }
$$

Based on (2) and (3), we obtain that

$$
\ln \left(\frac{Y_{i}}{L_{i}}\right)=a+p \ln \left(\frac{K_{i}}{L_{i}}\right)+(d-1) \ln L_{i}+\mathbf{X}_{i} \mathbf{b}+\mathbf{Z}_{i} \mathbf{c}+\varepsilon_{i},
$$

where $\ln A_{i}=a+\varepsilon_{i}$. $a$ measures the mean efficiency level across firms, and $\varepsilon_{i}$ is the firm-specific deviation from this mean. (4) is the basic equation to be estimated. The explanatory variables are $\left(\ln \left(K_{i} / L_{i}\right), \ln L_{i}, \mathbf{X}_{i}, \mathbf{Z}_{i}\right)$.

Let $Z_{1 i}$ denotes the variable 'innovation activity', and $\mathbf{Z}_{2 i}$ denotes a row vector of the other variables in $\mathbf{Z}_{i}$ than the 'innovation activity' variable. We assume that $\varepsilon_{i}$ is statistically independent of $\left(\ln \left(K_{i} / L_{i}\right), \ln L_{i}, \mathbf{Z}_{2 i}\right)$. However, we suspect $Z_{1 i}$ and each component of $\mathbf{X}_{i}$ to be endogenous variables, and we cannot therefore assume that each of these variables is statistically independent of $\varepsilon_{i}$.

\subsection{A two-step procedure}

In order to account for the potential bias in (i) and (ii) in Sect. 4.2, we carry out the following two-step procedure: In the first step, which corresponds to the second step 
in Hall et al. (2009, 2013), each component of $\mathbf{X}_{i}$ is regressed on a set of explanatory variables $\mathbf{V}_{i}$ using logistic regression, where each component of $\mathbf{X}_{i}$ is a dummy variable that is only available for firms with innovation activity. We have tested for several combinations of the other explanatory variables than the key regressors listed in Sect. 3.3. The variables in $\mathbf{V}_{i}$ are selected in order to avoid the problem of multicollinearity in the second step where this selection is based on calculations of the variance inflation factor (VIF). We have included the following variables in $\mathbf{V}_{i}$ : firm age, the number of employees, and geographic markets. The same set of explanatory variables is used in the study of innovation activity in Børing et al. (2016), except that we do not include dummy variables which account for manufacturing industrial sectors in $\mathbf{V}_{i}$ due to the multicollinearity problem.

In the logistic regressions, firm age is a continuous variable, while geographic markets are dummy variables. The number of employees is a categorical variable with the following categories: 5-9 employees, 10-49 employees (the reference category), 50-99 employees, and at least 100 employees. The predicted values from the logistic regressions are obtained. Let $\hat{\mathbf{X}}_{i}$ denotes a row vector of these predicted values where each component of $\hat{\mathbf{X}}_{i}$ is a continuous variable that takes values for both firms with and without innovation activity.

In the second step, we estimate the equation in (4), except that $\mathbf{X}_{i}$ is replaced with $\hat{\mathbf{X}}_{i}$ from the first step. The second step corresponds to the third step in Hall et al. (2009, 2013). In order to account for the potential bias in (i), we use a binary treatment model in the second step (the command 'ivtreatreg' in Stata), where the (binary) treatment variable is the variable 'innovation activity'. ${ }^{8}$ Depending on the model type specified, 'ivtreatreg' provides consistent estimation of average treatment effects under the hypothesis of "selection-on-unobservables" (i.e. treatment endogeneity) by using instrumental variables (IV) (Cerulli 2014). We use the direct-2sls model (IV regression estimated by direct two-stage least squares) as the treatment model, since we prefer not to specify the binary nature of the treatment variable.

Based on the study by Buhai et al. (2017), the following explanatory variables other than the key regressors are used in the IV (2SLS) regressions: the log of the average capital intensity, the log of the number of employees, proportion of females of total employees, average age of employees, educational level, manufacturing industrial sectors, and the variable 'innovation activity'. All these explanatory variables (including 'innovation activity') are used as control variables in the IV (2SLS) regressions.

Explanatory variables as the log of the average capital intensity and the log of the number of employees in the second step follow from the production function in (1), while the variables in $\mathbf{Z}_{i}$ are the other explanatory variables than $\left(\ln \left(K_{i} / L_{i}\right), \ln L_{i}\right)$ and the key regressors. All explanatory variables in the second step are continuous, except for the following dummy variables: innovation activity, and manufacturing

\footnotetext{
${ }^{8}$ Cerulli (2014) claims that the 'ivtreatreg' command implements a series of methods for treatmenteffects estimation under treatment endogeneity that use only conditional-moment restrictions, and that these methods are more robust than those implemented by 'etregress' or 'gsem'.
} 
industrial sectors. The calculations in the second step indicate that we have no serious multicollinearity problem. ${ }^{9}$

In the productivity equation in the third step in Hall et al. (2009), labour productivity (i.e. real sales per employee, in $\operatorname{logs}$ ) is a linear function of investment intensity (their proxy for physical capital), product and process innovation (proxied by the predicted probabilities of product and process innovation), and a disturbance or error term. They emphasize that 'using these predicted probabilities instead of the observed indicators is a way to address the issue of potential endogeneity (and measurement errors in variables) of the knowledge inputs' (p. 23), where product and process innovation are these knowledge inputs. ${ }^{10}$ The predicted probabilities of product and process innovation correspond to our predicted values of the variables that account for CSR objectives for innovations, which are also predicted probabilities. Including the predicted values of the key regressors from the first step accounts for the fact that all manufacturing firms may have some kind of innovative effort, although only some report innovation activity (and thus have answered the question about the objectives for innovations).

\subsection{The excluded instruments}

The direct-2sls model requires that the variables to be used as excluded instruments are specified. We suggest the importance of the following factors as excluded instruments: In the CIS survey, firms were asked about the importance of factors for lack of engagement in innovation activities or preventing ongoing innovation activities during the period 2011-2013. The factors are grouped into three main areas: three cost factors (F1)-(F3), four knowledge factors (F4)-(F7), and two market factors (F8)-(F9). The factors are: (F1) innovation costs too high, (F2) lack of funds within an enterprise or its enterprise group, (F3) lack of finance from sources outside an enterprise, (F4) difficulties in retaining or recruiting qualified personnel, (F5) lack of information on technology, (F6) lack of information on markets, (F7) difficulty in finding cooperation partner for innovation, (F8) market dominated by established enterprises, and (F9) uncertain demand for new products.

Let $I_{j}$ be the $j$ th potential excluded instrument, which is based on the $j$ th factor $\mathrm{F} j, j=1,2, \ldots, 9$. All potential (excluded) instruments are dummy variables. The instrument $I_{j}$ is equal to 1 if a firm stated that factor $\mathrm{F} j$ is (highly or moderately) important for lack of engagement in innovation activities or preventing ongoing innovation activities during the period 2011-2013, and 0 otherwise.

The instruments must be both relevant and exogenous. In order to validate both requirements, we follow the strategy in Chang and Kang (2018). First, we validate

\footnotetext{
${ }^{9}$ We find that VIF $<4$ for each of the explanatory variables in all regressions in the second step (weighted results). These calculations are based on linear regression, since Stata calculates the VIFs for the explanatory variables specified in a linear regression model.

${ }^{10}$ Hall et al. (2009) also emphasize that 'using the predicted value instead of the realized value is also a sensible way to instrument the innovative effort in the knowledge production function in order to deal with the simultaneity problem between R\&D effort and the expectation of innovative success' (p. 20).
} 
relevance. Based on how each instrument is measured, it is likely that all instruments are related to innovation activity. We have also carried out a two-sample Kolmogorov-Smirnov test for each instrument. The test is used to determine whether there are any differences in the distribution of the variable 'innovation activity' for the two values of the $j$ th instrument (i.e. for $I_{j}=0$ and $I_{j}=1$ ). We find that the hypothesis that the variable 'innovation activity' for $I_{j}=0$ contains smaller values than for $I_{j}=1$ is significant at the $1 \%$ level for all instruments, except that the hypothesis is only significant at the $10 \%$ level for F7-difficulty in finding cooperation partner for innovation (unweighted results, since weights are not allowed when using the command 'ksmirnov' in Stata). These results indicate that the instruments, except F7, are significantly associated with the 'innovation activity' variable.

Second, the instruments should also be exogenous. In order to test the exogeneity requirement, we estimate model (4) for each instrument based on the two-step procedure in Sect. 4.4, where we use all firms in the final sample (weighted results). We also calculate two tests of endogeneity in each regression: the Wu-Hausman F test and the Durbin-Wu-Hausman chi-sq test. The null hypothesis of the two tests is that the variable 'innovation activity' can be treated as exogenous. Both test statistics are found to be significant at the $1 \%$ level for F2, F3, F7 and F8, so we reject the null hypothesis and continue to treat the 'innovation activity' variable as endogenous for these factors. We also reject the null hypothesis for F1, F6 and F9, since both test statistics are found to be significant at the $10 \%$ level for these factors. However, we find that none of the tests are significant even at the 10\% level for F4 (difficulties in retaining or recruiting qualified personnel) and F5 (lack of information on technology), so we do not reject the null hypothesis for these two factors. We therefore use F4 and F5 as instruments in the analysis. In Table 3, where we present the estimation results based on the final sample, both factors are used as instruments. As seen from the table, neither the $\mathrm{Wu}$-Hausman $\mathrm{F}$ test nor the Durbin-Wu-Hausman chi-sq test is found to be significant in any of the regressions.

\section{Descriptive statistics}

Table 1 shows that many firms with innovation activity adopt both the 'environmental objective' and the 'health or safety objective'. We find that the proportion of those adopting the objective of improving health or safety of the employees (71\%) is higher than the proportion of those that adopt the objective of reducing environmental impacts (64\%).

Figure 1 shows the relative productivity level by CSR objective for innovations and number of employees based on the final sample of firms with innovation activity measured as the ratio of 'the average productivity level among firms with the specified number of employees that adopt the objective' to 'the average productivity level among all firms with the same specified number of employees'. We see that the relative productivity level is higher among all firms which adopt the 'environmental objective' than among all firms which adopt the 'health or safety objective'. This 


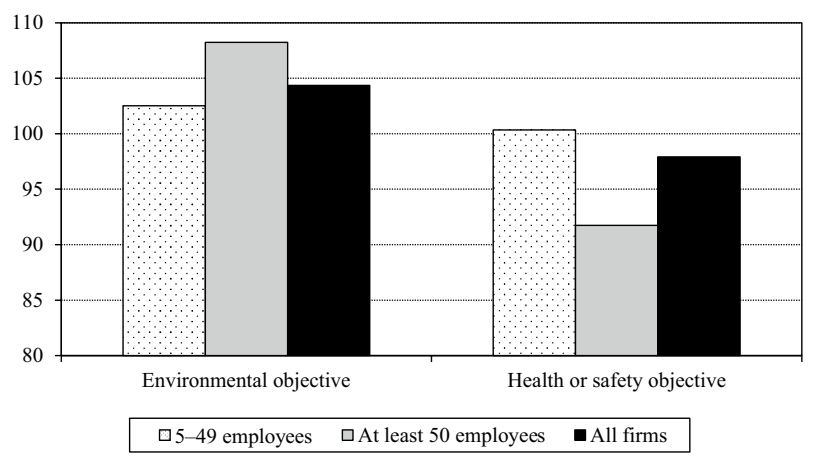

Fig. 1 The relative productivity level by CSR objective for innovations and number of employees, final sample of firms with innovation activity, weighted results. Notes: (1) For each of the CSR objectives for innovations and each group of employees, the relative productivity level is measured as the ratio of 'the average productivity level among firms with innovation activity with the specified number of employees that adopt the objective' to 'the average productivity level among all firms with innovation activity with the same specified number of employees'. (2) For the category 'all firms', the relative productivity level is measured as the ratio of 'the average productivity level among firms with innovation activity that adopt the objective' to 'the average productivity level among all firms in the final sample'. (3) The relative productivity level is measured in per cent in the figure

holds for both small firms (defined as those with 5-49 employees) and large firms (at least 50 employees).

As seen in Fig. 1, the average productivity level among large firms that adopt the 'environmental objective' is higher than the average productivity level among all large firms with innovation activity, while the average productivity level among large firms that adopt the 'health or safety objective' is relatively lower. The differences in these average productivity levels are less among small firms and all firms with innovation activity. This indicates that the productivity level is positively related to the objective of reducing environmental impacts and negatively related to the objective of improving health or safety of the employees in large firms, and not significantly related to each of the CSR objectives for innovations in small firms.

We see from Table 1 that two-thirds of the firms in the final sample only sell their products in the Norwegian market, while about one-third of the firms sell their products both in Norway and abroad. Very few of the firms only sell their products abroad (2\%).

The table shows that the proportion of employees with primary education (39\%) is about the same as the proportion of employees with secondary education (40\%) among all firms in the final sample. We see that the proportion of employees with higher education is $14 \%$, while the proportion of employees with unknown educational level is $6 \%$.

Furthermore, we find that $19 \%$ of the firms in the final sample are included in the industrial sector 'manufacture of food products', which is used as the reference category in the estimations. Many firms are also included in the sector 'manufacture of fabricated metal products, except machinery and equipment' (17\%). To a limited extent, these two industrial sectors are environmentally regulated. 
This is seen from Table 2 which shows the intramural R\&D expenditures within the 'environmental' area in per cent of the total intramural $R \& D$ expenditures in the sector. If the intensity of environmental regulation is measured using this percentage, ${ }^{11}$ we see from the table that the intensity of environmental regulation in each of the two industrial sectors is lower than the corresponding intensity for all manufacturing sectors as a whole. The intensity of environmental regulation is highest in the industrial sector 'manufacture of non-metallic mineral products'. According to Table 1, very few firms in the final sample are included in the sector 'manufacture of basic pharmaceutical products and pharmaceutical preparations' $(0.3 \%)$, where there are very low intramural R\&D expenditures within the 'environmental' area (see Table 2).

\section{The estimation results}

\subsection{The effects of the key regressors}

Table 3 presents the estimated effects of the explanatory variables on the log of the firm's productivity level based on the final sample. In order to examine the relationship between the productivity level and the CSR objectives for innovations, the last column in the table shows the effects of the explanatory variables among all firms in the final sample. Since we further aim to investigate how this relationship is influenced by firm size, the two other columns in the table show the corresponding effects in small and large firms. Thus, we not only can compare how the effects of the key regressors, but also the effects of the other explanatory variables (i.e. the control variables), vary between small and large firms. As shown in the table, 'small' firms are defined as those with 5-49 employees, while 'large' firms are defined as those with at least 50 employees.

There are two reasons why we use these definitions of 'small' and 'large' firms. First, most of the firms in the final sample are small, where firm size is measured by the number of employees. For example, $18 \%$ of the firms in the final sample have at least 100 employees, and only $6 \%$ of the firms have at least 250 employees. In order to include a sufficient number of enterprises in the group of 'large' firms, we define this group as all firms with a lower limit of 50 employees. Second, according to the European Commission (EC), ${ }^{12}$ small enterprises have up to 50 employees, mediumsized enterprises have 50-249 employees, and large enterprises have at least 250 employees. 'Large' firms in our analysis therefore consist of medium-sized and large enterprises according to the EC definition.

\footnotetext{
11 Our measure of environmental regulation (intramural R\&D expenditures within the 'environmental' area) is based on the study by Kneller and Manderson (2012). They measure the stringency of environmental regulations by pollution abatement costs, and their results indicate that environmental R\&D and investment in environmental capital are stimulated by greater pollution abatement pressures.

12 See the Commission Recommendation of 6 May 2003 concerning the definition of micro-, small- and medium-sized enterprises.
} 
Table 2 Intramural R\&D expenditures within the 'environmental' area and total intramural R\&D expenditures in the manufacturing sector in 2015 by industrial sector

\begin{tabular}{|c|c|c|c|}
\hline Industrial sector & Environment & Total & $\%$ \\
\hline Manufacture of food products (10) & 26,521 & 803,360 & 3 \\
\hline Manufacture of beverages (11) & 497 & 16,385 & 3 \\
\hline Manufacture of textiles (13) & 3005 & 60,203 & 5 \\
\hline Manufacture of wearing apparel (14) & 0 & 15,477 & 0 \\
\hline Manufacture of leather and related products (15) & 0 & 0 & \\
\hline Manufacture of wood and products of wood and cork (16) & 7952 & 70,820 & 11 \\
\hline Manufacture of paper and paper products (17) & 11,446 & 110,901 & 10 \\
\hline Printing and reproduction of recorded media (18) & 0 & 40,864 & 0 \\
\hline Manufacture of coke and refined petroleum products (19) & 0 & 0 & \\
\hline Manufacture of chemicals and chemical products (20) & 45,683 & 976,420 & 5 \\
\hline $\begin{array}{l}\text { Manufacture of basic pharmaceutical products and pharmaceutical } \\
\text { preparations (21) }\end{array}$ & 210 & 333,754 & 0.1 \\
\hline Manufacture of rubber and plastic products (22) & 15,268 & 137,081 & 11 \\
\hline Manufacture of non-metallic mineral products (23) & 29,547 & 106,869 & 28 \\
\hline Manufacture of basic metals (24) & 72,887 & 509,962 & 14 \\
\hline $\begin{array}{l}\text { Manufacture of fabricated metal products, except machinery and } \\
\text { equipment (25) }\end{array}$ & 18,527 & $1,198,168$ & 2 \\
\hline Manufacture of computer, electronic and optical products (26) & 79,998 & $1,956,176$ & 4 \\
\hline Manufacture of electrical equipment (27) & 19,056 & 380,791 & 5 \\
\hline Manufacture of machinery and equipment n.e.c. (28) & 223,749 & $1,189,399$ & 19 \\
\hline Manufacture of motor vehicles, trailers and semi-trailers (29) & 15,356 & 161,217 & 10 \\
\hline Manufacture of other transport equipment (30) & 17,539 & $1,000,358$ & 2 \\
\hline Manufacture of furniture (31) & 7963 & 137,771 & 6 \\
\hline Other manufacturing (32) & 1301 & 165,144 & 1 \\
\hline Repair and installation of machinery and equipment (33) & 5359 & 348,621 & 2 \\
\hline All manufacturing sectors $(10-33)$ & 601,863 & $9,719,741$ & 6 \\
\hline
\end{tabular}

(1) The column 'environment' is the intramural R\&D expenditures (1000 NOK) within the 'environmental' area. (2) The 'environmental' area includes the thematic areas 'environmental technology', and 'land-based environment and society'. (3) 'Environmental technology': Technologies that directly or indirectly improve the environment, excluding $\mathrm{CO}_{2}$ handling, renewable energy and climate technology. Includes pollution control technologies, purification, more environmentally friendly products and production processes, more efficient resource management, noise reduction and technological systems that reduce environmental impact. (4) 'Land-based environment and society': Nature diversity, ecosystems and ecosystem services, pollution, waste and circular economics, land use, cultural heritage and environments. (5) The column 'total' is the total intramural R\&D expenditures (1000 NOK). (6) The column ' $\%$ ' measures the ratio of the column 'environment' to the column 'total'. (7) Two-digit NACE codes in parenthesis for industrial sector (SIC2007)

Source: Statistics Norway

We see from Table 3 that the predicted probability of adopting the objective of reducing environmental impacts has a significant negative effect on the productivity level among large firms while the effect is not significant for small firms. This effect 


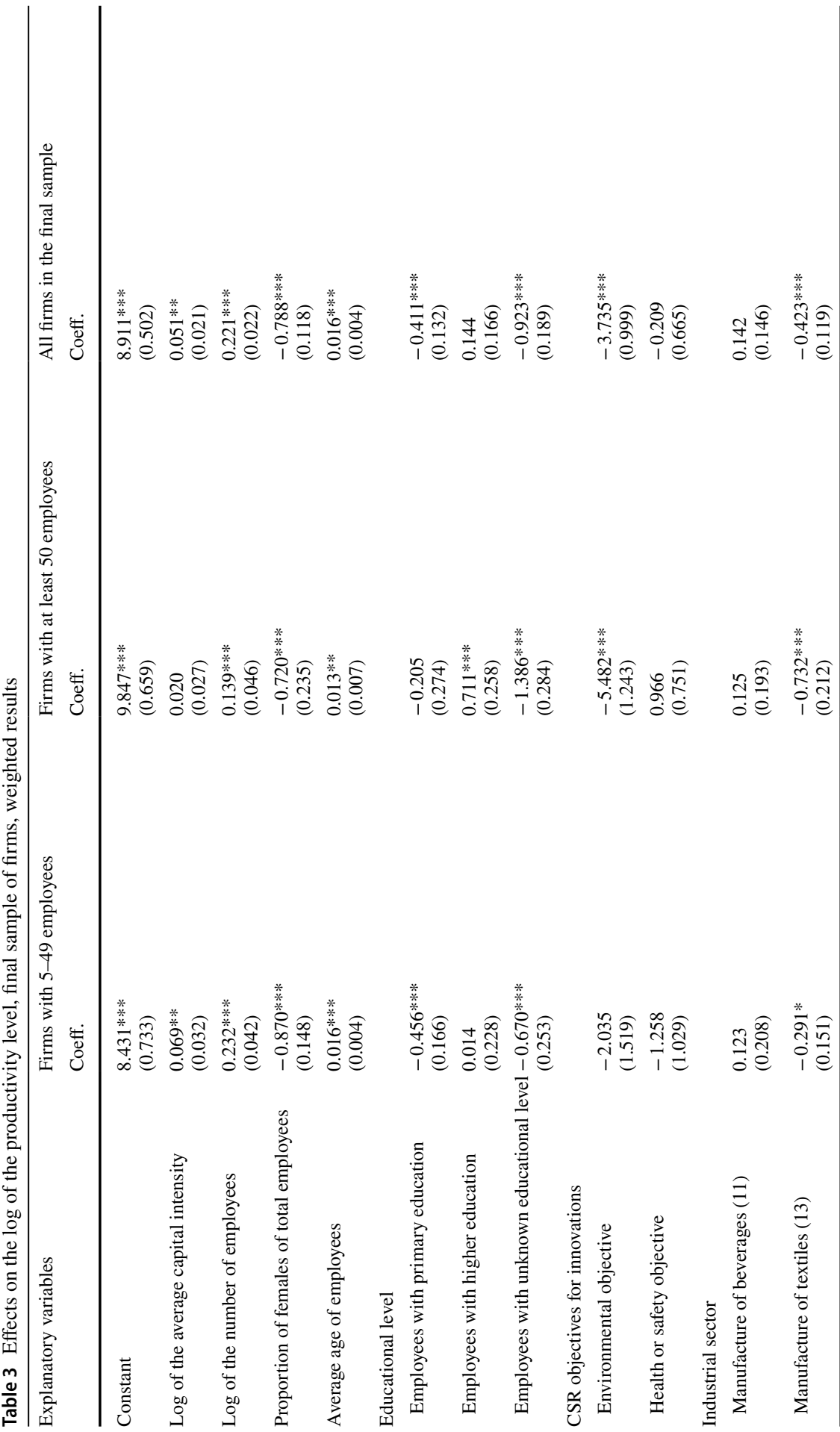




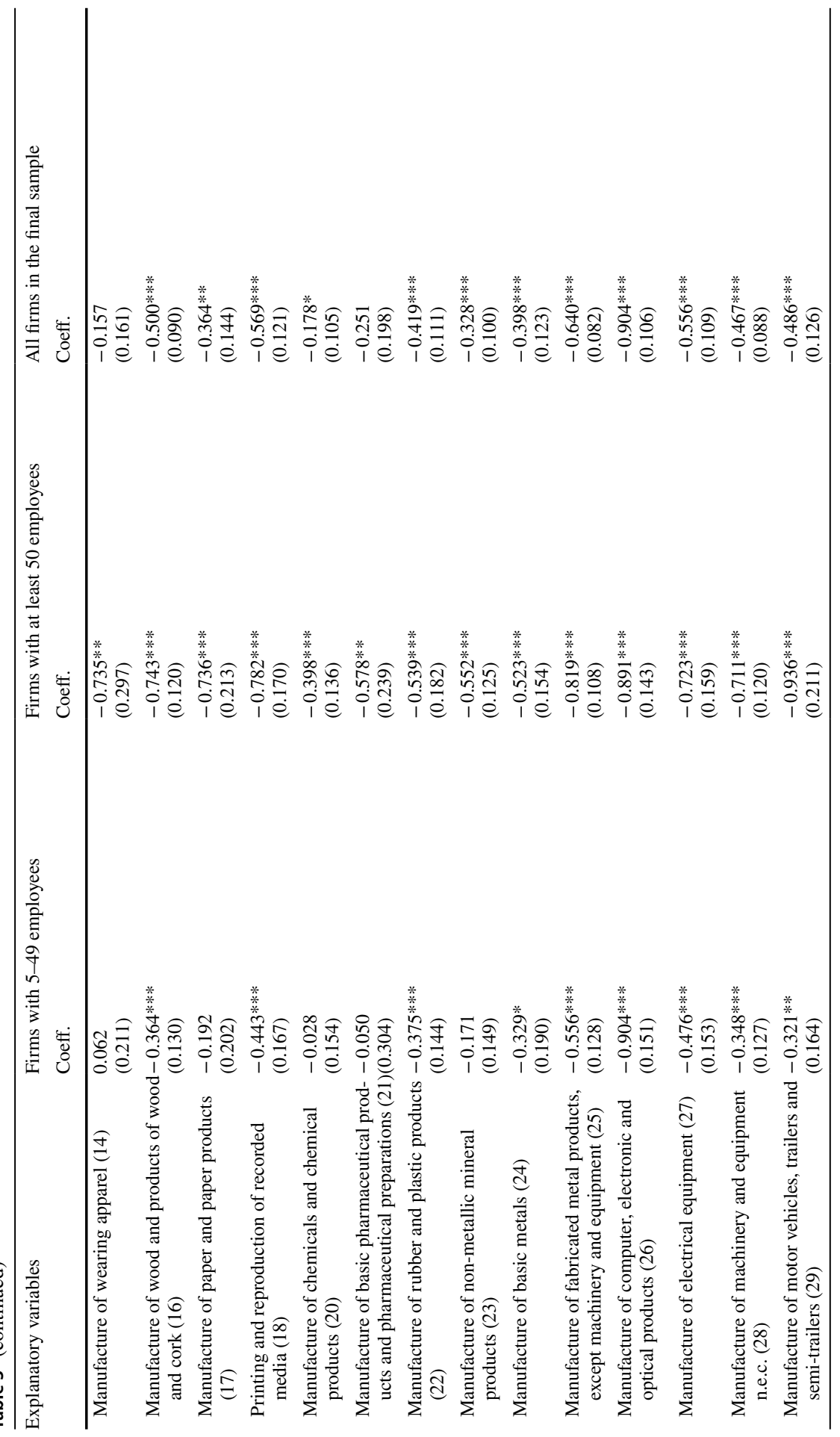




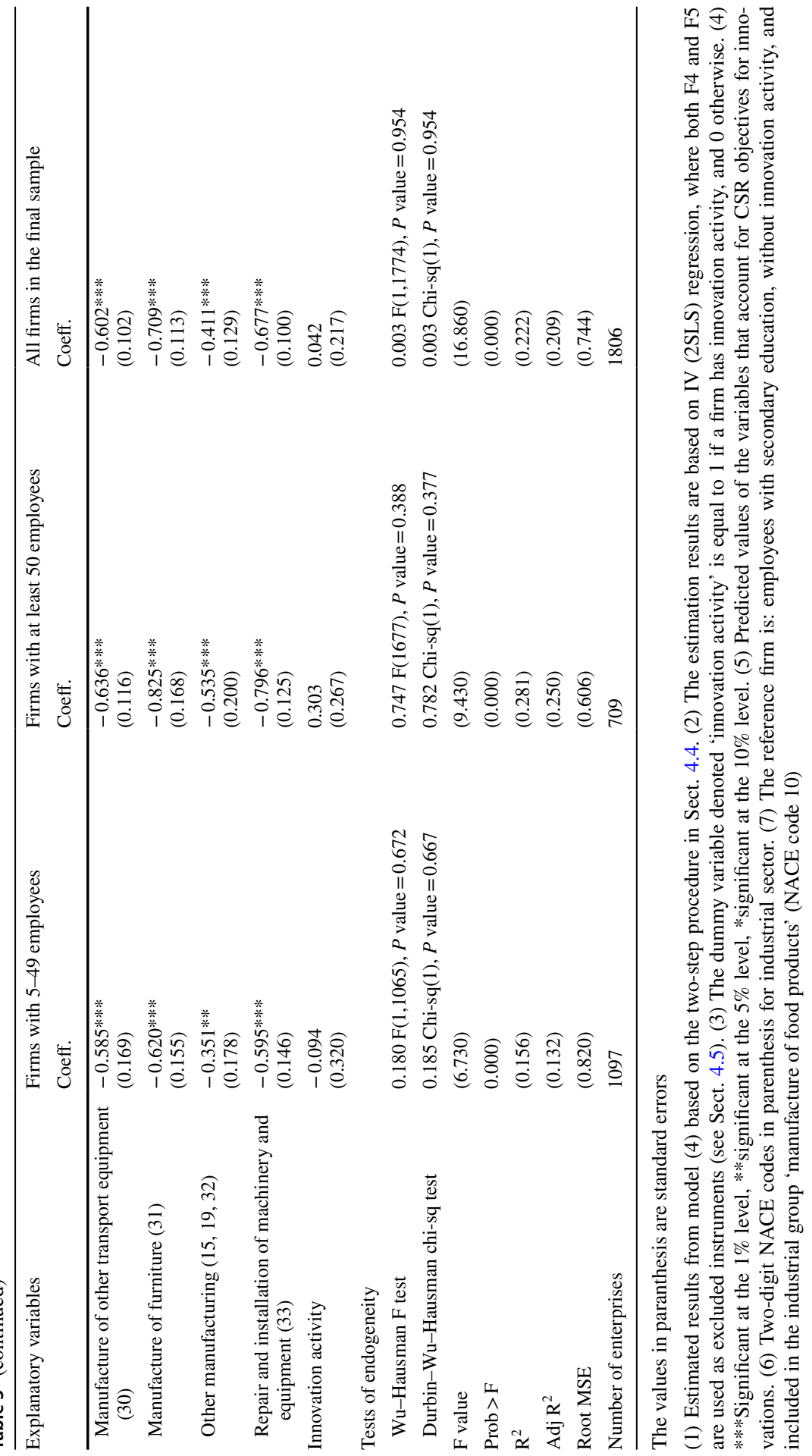


is also negative for all firms in the final sample. The predicted probability of adopting the objective of improving health or safety of the employees has no significant effect on the productivity level among all firms as a whole, and among small and large firms. ${ }^{13}$

These results do support neither $\mathrm{H} 1$ nor H2 (see Sect. 2). Based on the negative effect of the predicted probability of adopting the 'environmental objective', we conclude that our results indicate that 'it does not pay to be green'. This is partly in line with the results in Ghisetti and Rennings (2014), but not in line with those in Hart and Ahuja (1996), Russo and Fouts (1997), and King and Lenox (2002). Although reducing environmental impacts may be profitable in the long run due to improved environmental regulation (Beise and Rennings 2005; Ambec et al. 2013), this does not pay off in our short run analysis when environmental regulation may be seen as an external restriction. In the short run, the cost burden of the adoption of the objective of reducing environmental impacts seems to overcome the potential gains. The same conclusion can be found in Ghisetti and Rennings (2014) when they turn to externality-reducing innovations. However, well-designed environmental regulations might lead to improved competitiveness (Porter and van der Linde 1995), at least in the long run. This refers to the Porter Hypothesis which we comment on further in Sect. 6.2.

It is surprising that we find a non-significant effect of the predicted probability of adopting the 'environmental objective' among small firms, and a significant negative effect of this objective among large firms. The reason may be that small firms face certain constraints regarding managerial and financial resources which raise their costs of technology production and transfer relative to the costs for large firms (Eden et al. 1997). The resource argument against small firms is also highlighted in Welsh and White (1981) who argue that the size of small firms creates a special condition which they refer to as 'resource poverty'. On the other hand, small firms are possibly able to compensate for a lack of slack resources by being more flexible than large firms and which makes small firms more able to respond to environmental challenges and organizational changes (Dixon-Fowler et al. 2013). Small firms may therefore be able to counteract potential short-term negative productivity effects of reducing environmental impacts more so than large firms.

We also find it surprising that the effect of the predicted probability of adopting the 'health or safety objective' is not significant, and which is not in line with the study by Buhai et al. (2017), although their findings are limited to physical workplace health and safety environment dimensions. Thus, we cannot conclude whether or not the results of this study indicate that improving the health or safety of the

\footnotetext{
13 We still find that a firm's productivity level is significantly and negatively affected by the predicted probability of adopting the 'environmental objective' among firms with either 50-99 employees or at least 100 employees. This level is not significantly affected by the predicted probability of adopting the 'health or safety objective' among firms with at least 100 employees, while this effect is positive and significant at the $10 \%$ level among those with 50-99 employees. The productivity level is not significantly affected by the predicted probability of adopting one of the two CSR objectives among firms with either 5-9 employees or 10-49 employees. In each of these regressions, neither the Wu-Hausman F test nor the Durbin-Wu-Hausman Chi-square test is found to be significant even at the $10 \%$ level (see Sect. 4.5).
} 
employees as a CSR objective for innovations will increase a firm's productivity level. There may be several reasons why improved health or safety conditions at the workplace can increase the productivity level. One reason for this may be that employees are probably more satisfied and thus more productive, and they will be less likely to leave the firm (Buhai et al. 2017). Another reason may be that improvements in such conditions can lead to less sickness absenteeism of employees, and absenteeism can dampen firm productivity (Grinza and Rycx 2018). ${ }^{14}$

The non-significant effect of the predicted probability of adopting the "health or safety objective' may be related to the fact that this study is based on data which is cross-sectional. Our short-term analysis therefore does not deal with possible longterm benefits of improving health or safety conditions. The analysis in Buhai et al. (2017) is instead based on longitudinal data, and they emphasize that their results do not change if they use a longer time span. On the other hand, productivity gains can also be at the expense of workers' health and safety. For example, changes to work organization associated with outsourcing can adversely affect occupational health and safety (Quinlan and Mayhew 1999).

\subsection{The effects of the control variables}

Table 3 shows that the variable 'innovation activity', i.e. the treatment variable, is not significantly related to the productivity level among all firms in the final sample, and small and large firms. It is surprising that the relationship is non-significant for both small and large firms, since the ratio of 'the average productivity level among firms without innovation activity' to 'the average productivity level among those with innovation activity' is much lower among large firms (76\%) than among small firms (99\%) (weighted results).

The proportion of employees with higher education is positively related to the productivity level among large firms. There is a negative relationship between the productivity level and the proportion of employees with primary education among all firms and small firms. These results can be related to the fact that the educational level is higher among the employees in the large firms than among the employees in the small firms, on average. Weighted results show that the proportion of employees with primary education is lower, and the proportions of employees with secondary and higher education are higher, among large firms than among small firms. We find a negative relationship between the productivity level and the proportion of those with unknown educational level among all firms, and among small and large firms.

The proportion of females of total employees is negatively related to the productivity level, i.e. this level decreases with an increasing proportion of females. We also find that the productivity level increases with increasing average age among the employees. Both results hold for all firms in the final sample, and for small and large firms.

As seen from Table 3, the productivity level is positively affected by the average capital intensity in the industrial sectors where firms are included among all

\footnotetext{
14 The results in Grinza and Rycx (2018) show that the impact of sickness absenteeism on productivity is negative and significant only for small- and medium-sized firms.
} 
firms and small firms. Thus, small firms that are included in an industry with a high average capital intensity have a higher productivity level than small firms that are included in less capital-intensive industries, ceteris paribus. The same applies to all firms as a whole. The effect of average capital intensity at the industrial level is not significant for large firms. One reason for this non-significant effect is due to the control for industrial sectors, which already capture the effect of the intensity. If we do not control for industries, the intensity is found to be significant and positive for all firms, and both for small and large firms (at the $1 \%$ level). ${ }^{15}$

Large firms included in the industrial group 'manufacture of food products' (i.e. the reference group) have a higher productivity level than large firms included in all other industrial groups, with one exception: there are no significant differences in the productivity level between those included in the group 'manufacture of beverages' and the reference group, and the same applies to all firms and small firms. All firms as a whole and small firms included in the reference group also have a higher productivity level than those included in most of the other industrial groups.

In Sects. 5 and 6.1, we commented on environmental regulations, where the intensity of environmental regulation is measured by the percentage of the intramural R\&D expenditures within the 'environmental' area (see Table 2). Based on the industrial sectors in Table 3 where we find a significant (negative) effect of being included in a sector (at the 5\% level), we conclude that some of these industrial sectors have a higher intensity of environmental regulation than the reference group, while others have a relatively lower intensity. Therefore, we find no clear relationship between this intensity and productivity differences between the industries based on the firm-level data used in our study. This implies that we find no clear evidence in favor of our approach to test the Porter Hypothesis. The lack of unambiguous results when testing this hypothesis is partly in line with previous studies (Lanoie et al. 2008; Rubashkina et al. 2015; Wang and Shen 2016; Ghosal et al. 2018).

There is no clear relationship between the technological intensity and differences in the productivity level between the industrial groups either. This is interesting since we could expect a positive relationship. The reason is that previous studies (referred to in Sect. 2) have found that different forms of innovations are positively related to productivity (e.g. Hall et al. 2009; Mohnen and Hall 2013). Based on Eurostat's aggregation of the manufacturing sector according to technological intensity (two-digit level), ${ }^{16}$ the reference group is classified as a low-technology sector. Our results therefore show that firms included in one of the three other aggregated sectors (i.e. the high-technology, medium-high-technology and medium-low-technology sectors) and in industries in the low-technology sector (other than the reference group) have a lower firm productivity than the reference group. The explanation for this unclear relationship may be that the technological intensity is measured at the industrial level, while productivity is measured at the firm level.

\footnotetext{
15 We find that neither the Wu-Hausman F test nor the Durbin-Wu-Hausman Chi-square test is significant even at the $10 \%$ level in any of these regressions (see Sect. 4.5).

16 See (Eurostat 2018).
} 
Furthermore, we see from Table 3 that the number of employees is positively related to the productivity level. This level is therefore lower in firms that are less labour-intensive (ceteris paribus). It follows that the production function has non-constant returns to scale with respect to capital and labour since the estimate of the parameter $d$ is significantly different from 1 . Previous studies have also shown that firm size is positively related to firm productivity (Leung et al. 2008; Moral-Benito 2018).

\section{Conclusions}

We have examined how a firm's potential CSR objectives for innovations are related to its productivity level, and whether this relationship is affected by firm size. Two CSR objectives are examined: a firm's objective of reducing environmental impacts, and an objective of improving health or safety of the employees. The firm's productivity level is measured by labour productivity, determined as the turnover per employee. Both manufacturing firms with and without innovation activity are included in the sample of firms. Norwegian matched employer-employee register data, innovation data and data from the Amadeus database are used in the analysis.

The estimation results are based on IV (2SLS) regression. These results show that the predicted probability of adopting the objective of reducing environmental impacts has a significant negative effect on the productivity level among large firms, and a non-significant effect among small firms. We also find a negative effect for all firms as a whole. The productivity level is not found to be significantly affected by the predicted probability of adopting the objective of improving health or safety of the employees, and this applies to all firms as a whole, small firms and large firms.

Our results indicate that 'it does not pay to be green', at least for large firms. This can be related to the fact that our study is a short-term analysis. Reducing environmental impacts may be profitable in the long run as a result of improved environmental regulation. For example, environmental regulation can trigger the introduction of cleaner technologies or other forms of innovation, making production processes and/or products more efficient. In the short run, however, the effects of reducing environmental impacts are negative (for large firms) or not significant (for small firms). Small firms may be able to compensate for inadequate financial resources by being more flexible than large firms. This can result in small firms being able to respond to environmental challenges which can explain why we do not find a significant negative productivity effect for this group.

Finally, we emphasize that there are some limitations to this study. First, the cross-sectional nature of the data prevents us from examining whether potential CSR objectives for innovations are related to a firm's productivity level at a later time. ${ }^{17}$ According to Hsiao (2007), panel data have several advantages over cross-sectional or time-series data. Among these advantages, the availability of panel data can improve the efficiency of econometric estimates, and simplify computation and statistical

\footnotetext{
17 There may, however, be a time lag between the year when a firm's productivity level is measured (2013) and the period when its product or process innovations were developed (the period 2011-2013).
} 
inference. Second, in the analysis we measured firm's performance by the productivity level. Based on this measure, we tested whether a firm's productivity level is affected by its adoption of two CSR objectives for innovations. However, we have not tested for other firm performance measures such as profit per employee, for example. Unfortunately, we lack information about other performance measures than turnover per employee at the firm level. Third, we also lack information about (the monetary value of) the capital stock in each firm. Instead, we examined how a firm's productivity level is affected by the average capital intensity in those industries where firms are included. We therefore need further evidence of whether and how potential CSR objectives for innovations are related to different firm performance measures based on cross-sectional or panel data, and whether these relationships are affected by firm size.

\section{Compliance with ethical standards}

Conflict of interest The author declares that he has no conflict of interest.

Ethical approval This article does not contain any studies with human participants or animals performed by the author.

Open Access This article is distributed under the terms of the Creative Commons Attribution 4.0 International License (http://creativecommons.org/licenses/by/4.0/), which permits unrestricted use, distribution, and reproduction in any medium, provided you give appropriate credit to the original author(s) and the source, provide a link to the Creative Commons license, and indicate if changes were made.

\section{Appendix}

See Table 4.

Table 4 The source of the dependent variable and each of the explanatory variables

\begin{tabular}{|c|c|c|}
\hline Variable & Type of variable & Source \\
\hline Log of the productivity level & Dependent variable & Employer-employee register data \\
\hline $\begin{array}{l}\text { CSR objectives for innovations ('environmen- } \\
\text { tal objective', 'health or safety objective') }\end{array}$ & Key regressors & Innovation data \\
\hline Log of the average capital intensity & Control variable & $\begin{array}{l}\text { Total assets: Amadeus data, Num- } \\
\text { ber of employees: Employer- } \\
\text { employee register data }\end{array}$ \\
\hline Log of the number of employees & Control variable & Employer-employee register data \\
\hline Firm age & Control variable & Employer-employee register data \\
\hline Proportion of females of total employees & Control variable & Employer-employee register data \\
\hline Average age of employees & Control variable & Employer-employee register data \\
\hline Educational level & Control variables & Employer-employee register data \\
\hline Geographic markets & Control variables & Innovation data \\
\hline Innovation activity & Control variable & Innovation data \\
\hline Manufacturing industrial sectors & Control variables & Employer-employee register data \\
\hline
\end{tabular}




\section{References}

Ambec, S., Cohen, M. A., Elgie, S., \& Lanoie, P. (2013). The porter hypothesis at 20: Can environmental regulation enhance innovation and competitiveness? Review of Environmental Economics and Policy, 7(1), 2-22.

Audretsch, D. B. (1995). Innovation, growth and survival. International Journal of Industrial Organization, 13(4), 441-457.

Bai, X., \& Chang, J. (2015). Corporate social responsibility and firm performance: The mediating role of marketing competence and the moderating role of market environment. Asia Pacific Journal of Management, 32(2), 505-530.

Banbury, C. M., \& Mitchell, W. (1995). The effect of introducing important incremental innovations on market share and business survival. Strategic Management Journal, 16(S1), 161-182.

Baumann, J., \& Kritikos, A. S. (2016). The link between R\&D, innovation and productivity: Are micro firms different? Research Policy, 45(6), 1263-1274.

Beise, M., \& Rennings, K. (2005). Lead markets and regulation: A framework for analyzing the international diffusion of environmental innovations. Ecological Economics, 52(1), 5-17.

Black, S. E., \& Lynch, L. M. (2004). What's driving the new economy? The benefits of workplace innovation. The Economic Journal, 114(493), F97-F116.

Bocquet, R., Le Bas, C., Mothe, C., \& Poussing, N. (2017). CSR, innovation, and firm performance in sluggish growth contexts: A firm-level empirical analysis. Journal of Business Ethics, 146(1), 241-254.

Børing, P. (2014). The impact of manufacturing firms' use of academic workers on their productivity level. Bulletin of Economic Research, 66(2), 156-172.

Børing, P., Fevolden, A., \& Herstad, S. (2016). Eager and able: A study of innovation activity among young, mature and old firms in Norway. Economics Bulletin, 36(1), 291-297.

Buhai, I. S., Cottini, E., \& Westergaard-Nielsen, N. (2017). How productive is workplace health and safety? The Scandinavian Journal of Economics, 119(4), 1086-1104.

Cainelli, G., Evangelista, R., \& Savona, M. (2004). The impact of innovation on economic performance in services. The Service Industries Journal, 24(1), 116-130.

Cainelli, G., Evangelista, R., \& Savona, M. (2006). Innovation and economic performance in services: A firm-level analysis. Cambridge Journal of Economics, 30(3), 435-458.

Cefis, E., \& Marsili, O. (2005). A matter of life and death: Innovation and firm survival. Industrial and Corporate Change, 14(6), 1167-1192.

Cefis, E., \& Marsili, O. (2006). Survivor: The role of innovation in firms' survival. Research Policy, 35(5), 626-641.

Cerulli, G. (2014). ivtreatreg: A command for fitting binary treatment models with heterogeneous response to treatment and unobservable selection. The Stata Journal, 14(3), 453-480.

Chang, J., \& Kang, Y. (2018). Instrumental variable estimates of the effect of management practices on firm performance in korean firms. Journal of Labor Research, 17, 1-20.

Chatterji, A. K., Levine, D. I., \& Toffel, M. W. (2009). How well do social ratings actually measure corporate social responsibility? Journal of Economics \& Management Strategy, 18(1), 125-169.

Crépon, B., Duguet, E., \& Mairesse, J. (1998). Research, innovation and productivity: An econometric analysis at the firm level. Economics of Innovation and New Technology, 7(2), 115-158.

Crespi, G., Criscuolo, C., Haskel, J., \& Hawkes, D. (2006). Measuring and understanding productivity in UK market services. Oxford Review of Economic Policy, 22(4), 560-572.

del Río, P., Romero-Jordán, D., \& Peñasco, C. (2017). Analysing firm-specific and type-specific determinants of eco-innovation. Technological and Economic Development of Economy, 23(2), 270-295.

Díaz-García, C., González-Moreno, Á., \& Sáez-Martínez, F. J. (2015). Eco-innovation: Insights from a literature review. Innovation: Organization \& Management, 17(1), 6-23.

Dixon-Fowler, H. R., Slater, D. J., Johnson, J. L., Ellstrand, A. E., \& Romi, A. M. (2013). Beyond "does it pay to be green?" A meta-analysis of moderators of the CEP-CFP relationship. Journal of Business Ethics, 112(2), 353-366.

Eden, L., Levitas, E., \& Martinez, R. J. (1997). The production, transfer and spillover of technology: Comparing large and small multinationals as technology producers. Small Business Economics, 9(1), 53-66.

Eurostat. (2018). Glossary:High-tech classification of manufacturing industries. https://ec.europa.eu/ eurostat/statistics-explained/index.php?title=Glossary:High-tech_classification_of_manufacturing_ industries. 
Freeman, R. E. (1984). Strategic management: A stakeholder perspective. Englewood Cliffs, NJ: Prentice-Hall.

Ghisetti, C., \& Rennings, K. (2014). 'Environmental innovations and profitability: How does it pay to be green? An empirical analysis on the German innovation survey. Journal of Cleaner Production, 75, 106-117.

Ghosal, V., Stephan, A., \& Weiss, J. F. (2018). Decentralized environmental regulations and plant-level productivity. CESifo working paper no. 7255.

Grinza, E., \& Rycx, F. (2018). The impact of sickness absenteeism on productivity: New evidence from Belgian matched panel data. IZA DP no. 11543.

Hall, B. H. (2011). Innovation and productivity. Nordic Economic Policy Review, 2, 167-204.

Hall, B. H., Lotti, F., \& Mairesse, J. (2009). Innovation and productivity in SMEs: Empirical evidence for Italy. Small Business Economics, 33(1), 13-33.

Hall, B. H., Lotti, F., \& Mairesse, J. (2013). Evidence on the impact of R\&D and ICT investments on innovation and productivity in Italian firms. Economics of Innovation and New Technology, 22(3), $300-328$.

Haltiwanger, J. C., Lane, J. I., \& Spletzer, J. R. (1999). Productivity differences across employers: The roles of employer size, age, and human capital. The American Economic Review, 89(2), 94-98.

Hart, S. L., \& Ahuja, G. (1996). Does it pay to be green? An empirical examination of the relationship between emission reduction and firm performance. Business Strategy and the Environment, 5(1), 30-37.

Hashi, I., \& Stojčić, N. (2013). The impact of innovation activities on firm performance using a multistage model: Evidence from the Community Innovation Survey 4. Research Policy, 42(2), 353-366.

Hellerstein, J. K., \& Neumark, D. (1999). Sex, wages, and productivity: An empirical analysis of israeli firm-level data. International Economic Review, 40(1), 95-123.

Heyman, F. (2007). Firm size or firm age? The effect on wages using matched employer-employee data. Labour, 21(2), 237-263.

Hsiao, C. (2007). Panel data analysis-Advantages and challenges. TEST, 16(1), 1-22.

Jensen, J. B., McGuckin, R. H., \& Stiroh, K. (2001). The impact of vintage and survival on productivity: Evidence from cohorts of U.S. manufacturing plants. The Review of Economics and Statistics, 83(2), 323-332.

Katkalo, V. S., Pitelis, C. N., \& Teece, D. J. (2010). Introduction: On the nature and scope of dynamic capabilities. Industrial and Corporate Change, 19(4), 1175-1186.

King, A., \& Lenox, M. (2002). Exploring the locus of profitable pollution reduction. Management Science, 48(2), 289-299.

Kneller, R., \& Manderson, E. (2012). Environmental regulations and innovation activity in UK manufacturing industries. Resource and Energy Economics, 34(2), 211-235.

Lanoie, P., Patry, M., \& Lajeunesse, R. (2008). Environmental regulation and productivity: Testing the porter hypothesis. Journal of Productivity Analysis, 30(2), 121-128.

Leung, D., Meh, C., \& Terajima, Y. (2008). Productivity in Canada: Does firm size matter? (pp. 7-16). Autumn: Bank of Canada Review.

McWilliams, A., \& Siegel, D. (2001). Corporate social responsibility: A theory of the firm perspective. The Academy of Management Review, 26(1), 117-127.

Mohnen, P., \& Hall, B. H. (2013). Innovation and productivity: An update. Eurasian Business Review, $3(1), 47-65$.

Moral-Benito, E. (2018). Growing by learning: Firm-level evidence on the size-productivity nexus. SERIEs, 9(1), 65-90.

Pfeifer, C., \& Wagner, J. (2014). Age and gender effects of workforce composition on productivity and profits: Evidence from a new type of data for German enterprises. Contemporary Economics, 8(1), 25-46.

Porter, M. E., \& van der Linde, C. (1995). Toward a new conception of the environment-competitiveness relationship. Journal of Economic Perspectives, 9(4), 97-118.

Quinlan, M., \& Mayhew, C. (1999). The effects of outsourcing on occupational health and safety: A comparative study of factory-based workers and outworkers in the Australian clothing industry. International Journal of Health Services, 29(1), 83-107.

Rubashkina, Y., Galeotti, M., \& Verdolini, E. (2015). Environmental regulation and competitiveness: Empirical evidence on the porter hypothesis from European manufacturing sectors. Energy Policy, $83,288-300$. 
Russo, M. V., \& Fouts, P. A. (1997). A resource-based perspective on corporate environmental performance and profitability. The Academy of Management Journal, 40(3), 534-559.

Saeidi, S. P., Sofian, S., Saeidi, P., Saeidi, S. P., \& Saaeidi, S. A. (2015). How does corporate social responsibility contribute to firm financial performance? The mediating role of competitive advantage, reputation, and customer satisfaction. Journal of Business Research, 68(2), 341-350.

Stoian, C., \& Gilman, M. W. (2017). Corporate social responsibility that 'pays': A strategic approach to CSR for SMEs. Journal of Small Business Management, 55(1), 5-31.

Syverson, C. (2011). What determines productivity? Journal of Economic Literature, 49(2), 326-365.

Torelli, C. J., Monga, A. B., \& Kaikati, A. M. (2012). Doing poorly by doing good: Corporate social responsibility and brand concepts. Journal of Consumer Research, 38(5), 948-963.

van Ours, J. C., \& Stoeldraijer, L. (2011). Age, wage and productivity in Dutch manufacturing. De Economist, 159(2), 113-137.

Walker, K., \& Dyck, B. (2014). The primary importance of corporate social responsibility and ethicality in corporate reputation: An empirical study. Business and Society Review, 119(1), 147-174.

Wang, Y., \& Shen, N. (2016). Environmental regulation and environmental productivity: The case of China. Renewable and Sustainable Energy Reviews, 62, 758-766.

Welsh, J., \& White, J. (1981). A small business is not a little big business. Harvard Business Review, 59(4), 18-27.

Wood, D. J. (1991). Corporate social performance revisited. The Academy of Management Review, 16(4), 691-718.

Wooldridge, J. M. (2002). Econometric analysis of cross section and panel data. Cambridge, MA: MIT Press.

Wright, P., \& Ferris, S. P. (1997). Agency conflict and corporate strategy: The effect of divestment on corporate value. Strategic Management Journal, 18(1), 77-83.

Youn, H., Hua, N., \& Lee, S. (2015). Does size matter? Corporate social responsibility and firm performance in the restaurant industry. International Journal of Hospitality Management, 51, 127-134.

Publisher's Note Springer Nature remains neutral with regard to jurisdictional claims in published maps and institutional affiliations. 